\title{
Macroeconomic Factors and Entrepreneurship in Nigeria
}

\author{
A Y Dutse ${ }^{1}$, Ibrahim Aliyu ${ }^{2}$ \\ ${ }^{1}$ Abubakar Tafawa Balewa University, Bauchi, Nigeria \\ ${ }^{2}$ Bauchi State University, Gadau, Bauchi, Nigeria \\ Correspondence:Ibrahim Aliyu, Bauchi State University, Gadau, Bauchi, Nigeria \\ E-mail:ibrahimaliyu93@yahoo.com
}

Received: September 11, 2017

Accepted: September 14, 2017

Online Published: September 20, 2017

\begin{abstract}
Provision of conducives environment to enhance the supply and sustainability of entrepreneurs has developed into a field of competition among countries of the world. In this respect, macroeconomic factors such as FBI, technology, power generation, trade openness etc are enhanced to boost entrepreneurship in a country. Thus, this study is designed to investigate the impact of those macroeconomic factors to entrepreneurship in Nigeria. Secondary data from World Bank data bank between 2006-2015 were used for the study and analyzed using STATA package. The Regression output revealed that most Nigerian macroeconomic factors have insignificant impact on the development of entrepreneurship in the country. It was therefore, recommended that, policy makers should pay attention to not only the volume of the macroeconomic factors but also their rhythm with entrepreneurship in the country.
\end{abstract}

Keywords: Macroeconomic Factors, Entrepreneurship, FBI.

\section{Introduction}

Entrepreneurship is gradually becoming the target of individuals, firms and governments, especially with the increasing effect of unemployment and competition world over. On the side of individual and government, day-by-day, it is becoming apparently clear that, governments cannot provide jobs all their citizens, even in the developed economies like United State (US) talkless of developing ones, therefore, they must both recourse to entrepreneurship(Luke, Verreynne \& Kearins, 2007). Competition has also presented firms with an unprecedented challenges, where non-entrepreneurial businesses being wiped out of the market by the entrepreneurial ones. As such, breeding young entrepreneurs stands as a promising gesture that, an economy will in a short while be ready to compete at regional and global market and dominate there. Thus, economic growth and development in this modern day, largely depend on entrepreneurial propensity of that economy. Governments, in virtually every economy are doing everything possible to create an environment necessary for evolution of new businesses. In this regard, various Nigerian governments have designed and implemented different programs aimed at boosting entrepreneurship in the economy.Banks such as Nigeria Industrial Bank (NIDB), Nigeria Bank for Commerce and Industry (NBCI), Nigeria Agricultural and Cooperative Bank 
(NACB), People's Bank, Community Banks etc, were established for that purpose. Some other programs aimed at supporting SMEs were: The World Bank Assisted SME Scheme, National Economic Reconstruction Fund (NERFUND), The Export Stimulation Loan Scheme (ESL), The Rediscounting and Refinancing Facility (RRF), The National Directorate of Employment (NDE), Fadama Programs and Poverty Alleviation Program/National Poverty Eradication Program (NAPEP). Yet, the result is not encouraging as revealed by SMEDAN survey of Micro, Small and Medium Enterprises (MSMEs) for the years 2010 and 2013, that, during the period MSMEs contribution to GDP could only rise by $1.93 \%(46.54 \%-48.47 \%)$ and Nigeria has a dream of becoming one of the 20 developed economies of the world through industrialization by the year 2020.This seriously calls for looking for other alternative solutions to the problem.

One of the alternatives in for government to take steps towards igniting entrepreneurial motivation in the economy. Literatures havedivided entrepreneurial motivations into pull and push factors. Pull factor are internal to the individual himself, risk taking habit, internal locus of control, need for achievement and passion for work. Push factors are externally driven factors mainly consist of macroeconomic factors such astechnology, trade openness, unemployment, human capital, cost of registering new business, cost of doing business, internationalization and capital formation(Driessen and Zwart, 2006). Therefore,supply of entrepreneurship is a result of both individual level factors and general economic factors. It therefore follows, that, policy makers can encourage entrepreneurship, by improving macroeconomic factors that affectentrepreneurs, through reforms that mayact to push for entrepreneurship(Khader, Rajan and Sen, 2014).

In Nigeria, just like in the traditional studies of entrepreneurship, it is always conceptualizeddetermine macroeconomic factors and be determined by pull factors alone. This view is account for, by heavy reliance solely on entrepreneurship theories that positioned entrepreneur as a mighty being, whichdetermines all economic factors but not being determined by any. Of recent, other economic theories are being used to explain how a number of macroeconomic factors determine entrepreneurship. Such studies are very limited on Nigerian economy, both in number and width and breath in terms of analysis and variable inclusion. Thus, this study is designed to test the impact of macroeconomic factors on entrepreneurship in Nigeria.

The study is guided by these hypotheses:

$\mathrm{H}_{01}$ : Technology has no significant impact on entrepreneurship in Nigeria

$\mathrm{H}_{02}$ : power generation has no significant impact on entrepreneurship in Nigeria

$\mathrm{H}_{03}$ : trade openness has no significant impact on entrepreneurship in Nigeria

$\mathrm{H}_{04}$ : unemployment has no significant impact on entrepreneurship in Nigeria

$\mathrm{H}_{05}$ : lending interest rste has no significant impact on entrepreneurship in Nigeria

The subsequent sections of the paper are: section (ii) which discussed literature review and theoretical framework, then section (iii) discussed research methodology. Data analysis and result are the trust of section (iv), then section (v) finally discussed conclusions and recommendations.

\section{Literature Review \\ 2.1 Concept of Entrepreneurship}

Entrepreneurship is now a multidimensional concept as it has defined from different perspective. Some researchers look at entrepreneurship from the economics view, sociology and psychology, others look at it from the management perspective, while others look at it from the social perspective, yet most researchers and practitioners looked at it from economic and management persfectives (Hannah, Orwa \& Bula, 2012).According to Praag, Mirijam and Hans (1995), Richard Cantillon was the first economist to acknowledge the entrepreneur as a key economic factor in his posthumous "Essai sur la nature du commerce en general" first published in 
1755. Cantillon looked at entrepreneur as responsible for all exchange and circulation in the economy. Cantillon's entrepreneur is an individual that equilibrates supply and demand in the economy and in this function bears risk or uncertainty. Say (1767-1832) regarded entrepreneur as a manager of a firm. Schumpeter defines entrepreneur as innovator who identify a new economic opportunity and the subsequently introduction of new ideas in the market (Bosma, Praag \& Wit, 2000).

Other researchers identified supply of financial capital, innovation, allocation of resources among alternative uses and decision-making as functions of an entrepreneur. Entrepreneurs identify opportunities, assemble required resources, implement a practical action plan, and harvest the reward in a timely, flexible way(Kirzner, 1997). These definitions have one thing in common, ie entrepreneur create business by taking risk of providing capital to test a newly conceived business idea through a planned allocation of resources. Therefore, it can follow that, entrepreneurship is establishing a new business. In this regard, Okeke, and Okechukwu (2014) argued that the most obvious form of entrepreneurship is that of starting new businesses.

\subsection{Macroeconomic Determinants of Entrepreneurship}

Cala, Arauzo-Carod andManjón-Antolín, (2015) argued that determinants of new business formation can be seen from the perspectives of cross-country, country specific and industrydeterminants. Durowoju (2014) observed that, as the world is overwhelmed by technological change, liberalization, outsourcing, and restructuring to rule business enterprises, limited financing and support; inadequate infrastructure, insecurity and lack of training/vocational facilities are believed to be responsible for slow business creation and growth in many economies. Thus, one can say technological change, liberalization, outsourcing, and restructuring to rule business enterprises are determinants from international perspective, while limited financing and support; inadequate infrastructure, insecurity and lack of training/vocational facilities are from determinants from the country perspective.

Some researchers also put those factors in their own words, example, Grieco (2007) puts them as market opportunities to earn profits, industry and timing specific structural features, presence of signals concerning market conditions, environmental contingences related to prices, taxes and wages. In line with this, Amat, Renart and García, (2014) outlined internationalization, finance, innovation and quality.

Romero and Martínez-Román, (2012) External Environment characteristics: Knowledge spillovers, university system and R\&D institutions, regulation and public support measures

From the forgoing, it is observed that, GDP, technology, trade openness, unemployment, human capital, cost of registering new business, cost of doing business, internationalization and capital formation are the main determinants of entrepreneurship in an economy.

\subsection{Review of Studies on Environmental Factors and Entrepreneurship}

GDP, technology, trade openness, unemployment, human capital, cost of registering new business, cost of doing business,internationalization,interest rate and capital formation were examined at different number and economies, using different type of data and having different resultsKhader, Rajan and Sen, (2014) examined GDP, business density, unemployment, interest rates and internet users in 110 countries of the world using data from World Bank, they found interest rate, access to internet and GDP per capita are the only significant determining determinants of entrepreneurship. Thereby,they tested five out of ten and found only three to be significant.

Kadocsa and Francsovics (2011) found Capital formation, export and Financing having significant impact on entrepreneurship in Hungerian economy. Amat,Renart and García,(2014)investigated factors responsible for business growth in Spainusing data from 250 Catalonian businesses. It was found that quality, innovation, 
internationalization and finance were shown to influence business growth and sustainability over time.Hájek, Nekolová, and Novosák, (2015) found entrepreneurship in the form of new business formation is positively associated with the quality of human capital, number of foreign owned businesses, quality of entrepreneurial climate in Czech Republic also with a data from World Bank.

Ogunro, (2014) summarized the challenges of Nigerian business environment as Power Supply, Poor Transportation Network and Connectivity, Insecurity, multiple tax system, unpredictability of government policies.In Nigeria, Onugu, (2005) used questionnaire and found management (human capital), access to finance, infrastructure, government policy inconsistencies and bureaucracy, environmental factors and multiple taxes and levies (cost of doing business), access to modern technology, trade openness as main determinants of entrepreneurship in Nigeria. Also Obasan, (2014) withquestionnaire administered to 80 small scale businessmen and women operators in Ogun State found inflation, infrastructural and government policy have significant impact on business growth and survival. Eniola and Entebang (2015) found a relationship between government policy and SME firm performance. Essien, (2014) used questionnaire on 234 operators of manufacturing SSBs in Akwa Ibom state. Results showed that power, strict rules on credit, interest rates, multiple taxation, absence of tax holiday, trade liberalization and poor patronage of made in Nigeria goods as their main problems.Chukwuma and Chukwuma, (2015) used secondary data Central Bank of Nigeria and Federal Office of Statistics for the period of 1970-2013. Theyfound inflation, exchange rate, government tax revenue, external finances and interest rate having a significant impact on the performance of small scale businesses in Nigeria. From the above, it can be seen how these economic indices were under researched in Nigerian economy. Another gap is how most of the researches relied on primary data which made them to draw conclusions on the economy based on results from a very small domain in the economy. This study intends to study the impact of GDP, technology, trade openness, power supply, unemployment, human capital, cost of registering new business, cost of doing business, internationalization, capital formation and, interest rate on entrepreneurship in Nigeria using secondary data.

\subsection{Theoretical Framework}

This study is anchored on Simple Representative Agent Models developed by it argued that an economy consist of two representatives ie a representative firm and a representative consumer.It also went further to argue that these economic agents always seek optimize by maximizingsome objective subject to the constraints they face from a number of macroeconomic factors. They include: consumerspreferences, availability of technology, endowments of resources available to consumers and firms.

\section{Methodology \\ 3.1 Research Design}

The study employed a cross sectional research design using a time series for a period of 10 years (2006-2015). The rationale behind cross sectional design is to capture the relationship among the modeled variables over this specified period of time. The decision to take a startingyear as 2006 and ending at 2015 was based on recency and availability of data.

\subsection{Source of Data}

All the data used for the study, were secondary data from World Bank. The rationale behind this type of data was to cover the whole nation with a non-perceptual data.

\subsection{Operationalization}

i. Entrepreneurship: is operationalized as the number of new businesses registered. 
ii. GDP was measure as GDP per capita but it has high correlation with Gross capita formation and cost of doing business, therefore was removed to avoid multicollinearity. Gross capita formation and cost of doing business were left because they have higher theoretical linkage with entrepreneurship than GDP.

iii. Power generation was measured on electric power consumption which is the production of power plants and combined heat and power plants less transmission, distribution, and transformation losses and own use by heat and power plants.

iv. Technology was also operationalized as ICT goods imports (\% total goods imports) ieICT goods imports include computers and peripheral equipment, communication equipment, consumer electronic equipment, electronic components, and other information and technology goods

v. Trade openness was measured onexternal balance on goods and services ie exports of goods and services minus imports of goods and services

vi. Unemployment was defined as the share of the labor force that is without work but available for and seeking employment.

vii. Human capita = share of people with tertiary education in population over 15 years of age but had to be dropped because of unavailability of data.

viii. Cost to register new business Cost to register a business is normalized by presenting it as a percentage of gross national income (GNI) per capita.

ix. Capital formation was defined as gross capital formation which consists of outlays on additions to the fixed assets of the economy plus net changes in the level of inventories.

$\mathrm{x}$. Interest rate is defined as lending interest rate ie bank rate that usually meets the short- and medium-term financing needs of the private sector. This rate is normally differentiated according to creditworthiness of borrowers and objectives of financing. The terms and conditions attached to these rates differ by country, however, limiting their comparability.

xi. Internationalization is measured by cost of export ie the fees levied on a 20-foot container in U.S. dollars. All the fees associated with completing the procedures to export or import the goods are included. These include costs for documents, administrative fees for customs clearance and technical control, customs broker fees, terminal handling charges and inland transport. The cost measure does not include tariffs or trade taxes. Only official costs are recorded.

\subsection{Model Specification}

A multiple regression model is specified as:

$\mathrm{Y}=\beta+\alpha 1 \mathrm{X} 1+\alpha 2 \mathrm{X} 2$ $+\alpha \mathrm{Xn}+\varepsilon$

Where:

$\mathrm{Y}$ is the dependent variable

$\beta$ is constant

$\alpha$ are the coefficients of the independent variables to be estimated

$\mathrm{X} 1, \mathrm{X} 2, \mathrm{Xn}$ are any number of independent variables

$\varepsilon$ is the error term

Therefore, the model forthe study becomes:

ENT $=\mathrm{f}(\mathrm{TECH}, \mathrm{POWG}, \mathrm{TRED}, \mathrm{UNEM}, \mathrm{INTR})$.

Where:

ENT is Entrepreneurship, TECH is Technology, TRED is Trade Openness, UNEM is Unemployment, POWG is Power Generationand, INTR is Interest Rate 
Thus, the structure of prediction shall be additive between the variables with multiplicative relationship between each variable and its coefficient as follows:

$\mathrm{ENTR}=\beta+\alpha 1 \mathrm{TECH}+\alpha 2 \mathrm{POWG}+\alpha 3 \mathrm{TRAD}+\alpha 4 \mathrm{UNEM}+\alpha 5 \mathrm{INTR}+\varepsilon \ldots$

3.5 Tool of Data Analysis

The data was analyzed using multiple linear regression analysis with STATA, to test the hypothesis about the impact of macroeconomic factors on entrepreneurship in Nigeria. This is because there are more oneindependent variables and entrepreneurship as dependent.

4. Data Analysis and Result

4.1 Tests for Multicolinearity

Table 1: Correlation Matrix

\begin{tabular}{|c|c|c|c|c|c|}
\hline & tech & powg & tred & intr & unem \\
\hline tech & 1.0000 & & & & \\
\hline powg & -0.2550 & 1.0000 & & & \\
\hline tred & 0.3474 & -0.5153 & 1.0000 & & \\
\hline intr & -0.0705 & -0.2242 & -0.4255 & 1.0000 & \\
\hline unem & 0.4347 & -0.5838 & 0.1456 & 0.1006 & 1.0000 \\
\hline
\end{tabular}

Source: Researcher's Computation, 2017

As it can be seen from table 1, there is no evidence of multicollinearity ( 0.7 and above) between any two of the above five independent variable, therefore, they are all qualified to run for multiple regression(Sekaran and Bougie, 2010).

4.2 Test of Hypotheses

Table 2: Regression Coefficient

- reg entr tech powg tred intr unem

\begin{tabular}{r|crr} 
Source & SS & df & MS \\
\hline $\begin{array}{r}\text { Model } \\
\text { Residual }\end{array}$ & $\begin{array}{r}236756431 \\
1.4446 \mathrm{e}+09\end{array}$ & 5 & 47351286.2 \\
\hline Total & $1.6814 \mathrm{e}+09$ & 9 & 186822171
\end{tabular}

$\begin{array}{lrr}\text { Number of obs } & =10 \\ \text { F( 5, 4) } & 0.13 \\ \text { Prob }>\text { F } & =0.9766 \\ \text { R-squared } & =0.1408 \\ \text { Adj R-squared } & =-0.9332 \\ \text { Root MSE } & =19004\end{array}$

\begin{tabular}{r|rrrrrr}
\hline entr & Coef. & Std. Err. & $t$ & $\mathrm{P}>|t|$ & [95\% Conf. Interval] \\
\hline \multirow{2}{*}{ tech } & 1076.434 & 4196.243 & 0.26 & 0.810 & -10574.21 & 12727.07 \\
powg & 196.3543 & 717.95 & 0.27 & 0.798 & -1796.995 & 2189.703 \\
tred & 149.9905 & 1478.218 & 0.10 & 0.924 & -3954.201 & 4254.182 \\
intr & 190.1452 & 11439.52 & 0.02 & 0.988 & -31571.05 & 31951.34 \\
unem & -63645.47 & 181742.2 & -0.35 & 0.744 & -568242.7 & 440951.8 \\
cons & 506499.8 & 1505609 & 0.34 & 0.753 & -3673740 & 4686739 \\
\hline
\end{tabular}

Source: Researchers Computation, 2017 
It can be seen from Table 2, that the model is not fitted as the F-statistics is not significant $(0.13>0.05)$, therefore, the coefficient of determination stands $14.08 \%$. this means that, all the five variables put together account for just $14 . .08 \%$ of the behavior or changes in the dependent variable and the rest $85.92 \%$ of it's behavior are as a result of other variables not included in our model. This confirmed that, technology, trade openness, unemployment, power generation, lending interest rate and foreign direct investment are very weak predictors of entrepreneurship in Nigeria.

Also, it can also be seen from the table, that, four of the five independent variables (technology, trade openness, power generation, lending interest rate and foreign direct investment) have positive but insignificant impacts on entrepreneurship as they have $0.810,0.798,0.924,0.988$ and 0.744 -values respectively. Unemployment on the other hand also has insignificant but negative impact on entrepreneurship in Nigeria with a t- and p-values of -0.35 and 0.744 respectively. As such, the null hypothesis, which states that: $\mathrm{H} 0$ macroeconomic indices have no significant impact on entrepreneurship in Nigeria is accepted.

This result contradicts Khader, Rajan and Sen, (2014) who found GDP, unemployment andinterest ratesas main determinants of entrepreneurship in 110 countries of the world using data from World Bank. It has also contra Onugu, (2005) who found access to finance, infrastructure, cost of doing business, access to modern technology and trade openness as main determinants of entrepreneurship in Nigeria with questionnaire

Based the above result, the researcher recourse to designing another less conservative model that accepts 0.9 or less as absent of multiple effect (multicollinearity) to test the impact of GDP, FDI capital formation, cost of doing business, cost of registering new business and cost of export as follows:

$\mathrm{ENTR}=\beta+\alpha 1 \mathrm{FDI}+\alpha 2 \mathrm{GDP}+\alpha 3 \mathrm{CAPF}+\alpha 4 \mathrm{COSD}+\alpha 5 \mathrm{COSR}+\alpha 6 \mathrm{COSS}+$

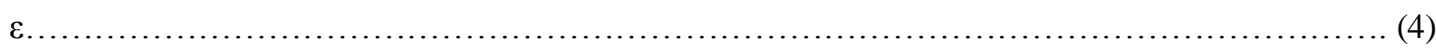

FDI is FDI, GDP is GDP, CAPF is Capital Formation, COSD is Cost of Doing Business, COSR is Cost of Registering New Business and COSS is Cost of Starting Business

Table 3: Correlation Matrix

\begin{tabular}{r|rrrrrr} 
& fdi & cose & cosr & capf & coss & gdp \\
\hline fdi & 1.0000 & & & & & \\
cose & 0.1333 & 1.0000 & & & & \\
$\operatorname{cosr}$ & -0.1282 & -0.6910 & 1.0000 & & & \\
$\operatorname{capf}$ & 0.1771 & 0.7486 & -0.8374 & 1.0000 & & \\
$\operatorname{coss}$ & -0.0633 & -0.7644 & 0.8814 & -0.8439 & 1.0000 & \\
gdp & -0.0804 & 0.7116 & -0.8891 & 0.8654 & -0.8876 & 1.0000
\end{tabular}

Source: Researchers Computation, 2017

All the independents variables above have a less 0.9 coefficient of correlation with one another, therefore qualified for multiple regression. 
Table 4: Regression Coefficient

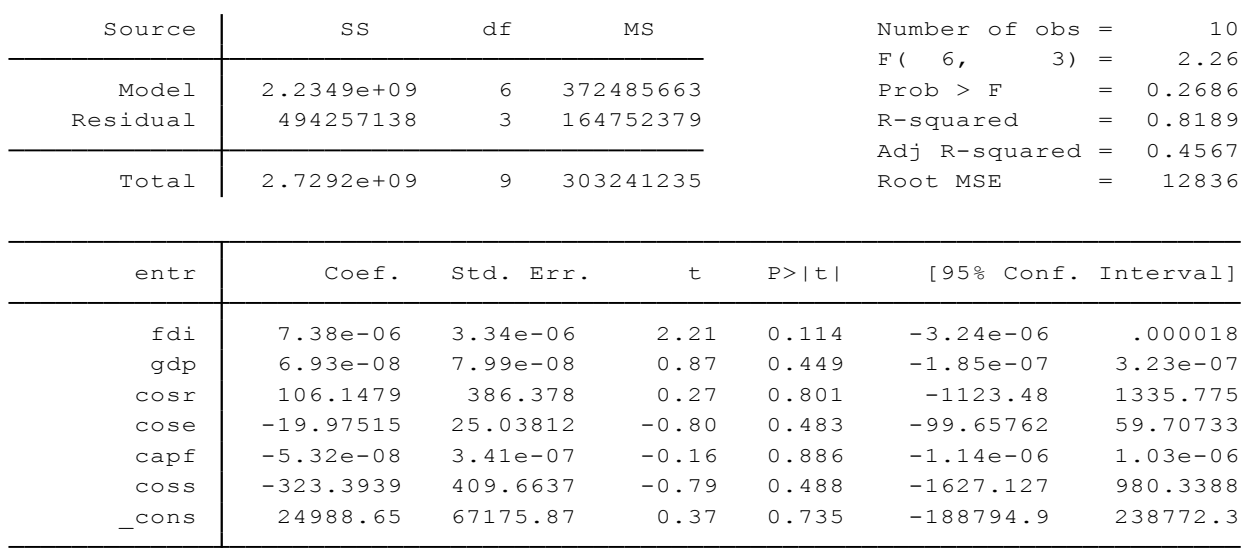

Source: Researchers Computation, 2017

The above result also shows an all through insignificant impact, with some impacts being positive as in the case of FDI, GDP, and COSR; while COSE, CAPF and COSS appeared to have negative impacts.

The issue of all-through insignificant results is less irritating than capital formation having a negative impact on entrepreneurship in an economy. It was therefore decided to test the impact of each variable on entrepreneurship in a simple linear regression and result in appendix A reveal that the negative impact of capital formation on entrepreneurship is a matter of mediation.

Table 5: Regression Coefficient

\begin{tabular}{|c|c|c|c|c|c|c|c|}
\hline Source & sS & $d f$ & \multicolumn{2}{|c|}{ MS } & & $\begin{array}{l}\text { Number of obs } \\
\text { F( } 5, \quad 4)\end{array}$ & $\begin{array}{r}10 \\
2.73\end{array}$ \\
\hline Model & $2.1108 e+09$ & 5 & 42 & 54066 & & Prob > F & 0.1759 \\
\hline Residual & 618350785 & 4 & 15 & 37696 & & R-squared & 0.7734 \\
\hline Total & $2.7292 e+09$ & 9 & 30 & 41235 & & Root MSE & 12433 \\
\hline entr & Coef. & std. & Err. & t & $P>|t|$ & [95\% Conf. & Interval] \\
\hline fdi & $5.80 e-06$ & $2.71 \mathrm{e}$ & -06 & 2.14 & 0.099 & $-1.72 e-06$ & .0000133 \\
\hline cose & -19.26223 & 24.2 & 38 & -0.79 & 0.471 & -86.56432 & 48.03986 \\
\hline $\cos r$ & -55.2774 & 328. & 487 & -0.17 & 0.874 & -966.0865 & 855.5317 \\
\hline capf & $8.76 e-08$ & $2.91 \epsilon$ & -07 & 0.30 & 0.778 & $-7.20 e-07$ & $8.95 e-07$ \\
\hline $\operatorname{coss}$ & -425.0871 & 380.2 & 464 & -1.12 & 0.326 & -1480.82 & 630.6462 \\
\hline _cons & 67147.09 & 44945 & 51 & 1.49 & 0.209 & -57641.66 & 191935.8 \\
\hline
\end{tabular}

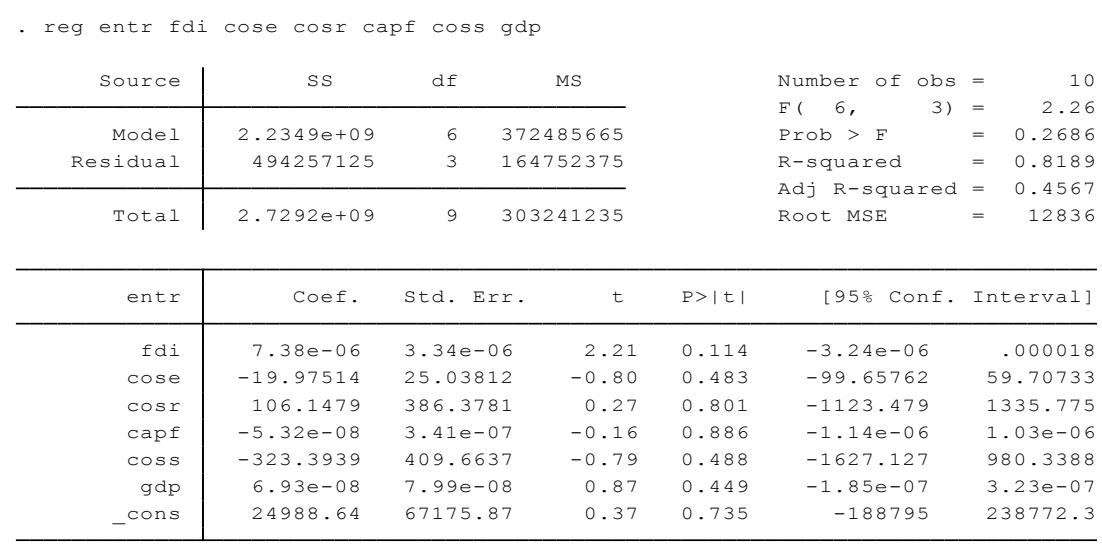

Source: Researchers Computation, 2017 
As it can be seen in the first table above when GDP was removed from the model, capital formation (CAPF) depict a positive coefficient but when GDP was added back, capital formation (CAPF) become negative again. This means that GDP has a negative mediating effect in the relationship between capital formation and entrepreneurship.

\section{Findings, Conclusion and Recommendation}

\subsection{Findings}

It is found that Macroeconomic factors are not good determinants of entrepreneurship in Nigeria as they have insignificant impacts on it.

It is also found that GDP has a negative mediating effect in the relationship between entrepreneurship and capital formation in the of additions outlays to the fixed assets of the economy such as land improvements, machinery and equipment purchases; and the construction of roads, railways, schools, offices, hospitals, private residential dwellings, and commercial and industrial buildings plus net changes in the level of inventories. This suggest that, these machineries and equipment are not produced by Nigerians, thereby, reduces the GDP when

\subsection{Conclusion}

Based on the above findings, it is concluded that, Nigerian macroeconomic environment is confused one and is not conducive for entrepreneurship. As such, any effort of government to encourage entrepreneurship through is will make little or no impact.

\subsection{Recommendation}

i. Policy makers should pay attention to not only the volumes macroeconomic indices, but also how rhymed are they to boosting entrepreneurship in the country.

ii. For the internationals, such as FDI and export, Nigeria should tactically renegotiate with her partners. This will deploy foreign investors to those sectors that have higher potential of buying and selling to Nigerians small business. It will also create market for Nigerian small businesses' products.

iii. Government should consider relaxing cost of export as it will ease marketing out of Nigerian small businesses' products.

\section{References}

Amat, O., Renart, M. A. \& García, M. J. (2014). Factors that determine the evolution of high growth businesses:Intangible Capital. 9(2), 1697-9818.

Bula, H. o. (2012). Evolution and theories of entrepreneurship: A critical review on the Kenyan perspective: International Journal of Business and Commerce, 1(11), 81-96.

Bosma, N., Praag M. \& Wit, G. (2000).Determinants of successful entrepreneurship: Research Report 0002/E

Cala, C. D., Arauzo-Carod, J. M. \& Manjón-Antolín, M. (2015). Determinants of new business formation-some lessons from the Czech Republic: Economics and Sociology. 8(1),147-156.

Chukwuma, N. K. \& Chukwuma, E. (2015). Implications of economic factors on small scale.

business performance in Nigeria: 1970 -2013: International Journal of Research in Business Management. 3(10), 23-30.

Durowoju, S.T. (2014). Roles of entrepreneurship in small and medium enterprises development in Nigeria: Review of Public Administration and Management. 3(5), 2315-7844. 
Eniola, A. A. and Entebang.(2015). Government policy and performance of small and medium business management:International Journal of Academic Research in Business and Social Sciences.5(2),2222-6990.

Essien, B. S. (2014). The Nigerian business environment and growth constraints of micro and small scale manufacturing industries: American International Journal of Social Science.3(6), 67-76.

Hájek, O., Nekolová, J. \& Novosák, J. (2015), Determinants of new business formation - some lessons fromthe Czech Republic: Economics and Sociology. 8(1), 147-156.

Kadocsa, G. \& Francsovics, A. (2011) Macro and micro economic factors of small enterprise competitiveness:Acta Polytechnica Hungarica. 8(1), 23-40.

Khader, S., Rajan, R. \& Sen M. (2014). Macro-economic factors affecting ease of business: Georgia Institute of Technology.

Kirzner, I. M .(1997). Entrepreneurial discovery and the competitive market process: An Austrian approach: Journal of Economic Literature. 3(5) 60-85.

Luke, B., Verreynne, M. \& Kearins, K. (2007). Measuring the benefits of entrepreneurship at different levels of analysis: Journal of Management \& Organization. 13, 312-330.

Obasan, K. A. (2013). The impact of business environment on the survival of small scale businesses in Nigeria: International Journal of Management and Business Research. 4 (3), 165-170.

Ogunro, V. O. (2014). Nigeria's business environment: issues challenges and prospects: InternationalJournal of Academic Research in Business and Social Sciences. 4(4), 2222-6990.

Onugu, B. A. N. (2005). Small and medium enterprises (SMEs) in Nigeria: Problems and prospects: Being a dissertation submitted to the St. Clements University in partial fulfilment of the requirements for the award of the Degree of Doctor of Philosophy in Managemen st. Clements University.

Praag, C., Mirijam V. \& Hans V. O. (1995) Determinants of willingness and opportunity to start as an entrepreneur:Kyklos. 48(4), 513-40.

Romero, I. \&Martínez-Román, J. A. (2012). Self-employment and innovation. Exploring the determinants of innovative behavior in small businesses:Research Policy. 41, 178- 189.

Sekaran, U., \& Bougie, R. (2010). Research methods for business: A skill building approach: John Willey \& Sons Ltd.

Taiwo, Falohun, Agwu. (2016). SMEs financing and its effects on Nigerian economic growth. European Journal of Business, Economics and Accountancy. 4( 4), 2056-6018.

Vavryshkuck,V. (2003). Small business in Ukraine: Macroeconomic determinants: Thesis Submitted inpartial fulilment of the Requirements for the Degree of Master of art in Economics, University Kyiv Mohyla Academy, Kyev

Williamson, S. (1999). Notes on Macroeconomic Theory: Dept. of Economics, University of Iowa, Iowa, IA 52242

\section{Copyrights}

Copyright for this article is retained by the author(s), with first publication rights granted to the journal. 